\title{
Stakeholder Perceptions Regarding eCRM: A Franchise Case Study
}

\author{
Kelley O'Reilly \& David Paper \\ Utah State University, Logan, UT, USA
}

k.o@aggiemail.usu.edu; david.paper@usu.edu

\begin{abstract}
Using a dual lens of Stakeholder Theory (ST) and Relationship Marketing (RM), this exploratory case study considers the perceptions and attitudes of each stakeholder regarding the initial design, development, and subsequent testing of an electronic customer relationship management (eCRM) tool. Through the use of in-depth interviews, member-checking interviews, and data from actual customer transactions, this study attempts to fill the gap in the literature by gaining a clear understanding of the objectives, goals, and perceptions of an eCRM vendor, franchisor senior company management, franchisees, and customers regarding eCRM. The results of this study reveal important implications for the informing sciences including the need to balance human and computer interaction, issues related to control, the impact that "electronic" systems may have on marketing relationships, and the importance of balancing the interests and expectations of all stakeholders.
\end{abstract}

Keywords: Electronic customer relationship management (eCRM), Customer relationship management (CRM), Internet customer relations, Internet loyalty, Internet relationship management, Stakeholder Theory, Relationship Marketing.

\section{Introduction}

In many ways, the Internet has changed the way we conduct our daily activities. Online shopping, social networking, and 'googling' for information are just a few examples of a new door that has been opened through the use of the Internet as the electronic portal to the world. For customers, easier availability of new products, access to more options, and the greatly expanded competitive landscape brought about by the Internet can all work together in a positive manner to provide greater choice, value, and pricing flexibility in many cases. For merchants, this same access to a world of new customers is of great potential benefit, but with it comes a world of new competitors. To survive and prosper in such a competitive environment, many marketers have recognized that, while vast opportunity may exist to attract new customers to their offerings, real value rests in keeping existing customers loyal to a brand. For many, the idea of "get there first and don't give them a reason to switch" is as true today as it was in the 1960s when more sophisticated models of marketing and brand management began to emerge. The idea that the value of existing

Material published as part of this publication, either on-line or in print, is copyrighted by the Informing Science Institute. Permission to make digital or paper copy of part or all of these works for personal or classroom use is granted without fee provided that the copies are not made or distributed for profit or commercial advantage AND that copies 1) bear this notice in full and 2) give the full citation on the first page. It is permissible to abstract these works so long as credit is given. To copy in all other cases or to republish or to post on a server or to redistribute to lists requires specific permission and payment of a fee. Contact Publisher@InformingScience.org to request redistribution permission. customers is greater than that of new customers is not new since it is well understood and recognized that the cost of acquiring new customers far exceeds the cost of keeping existing ones (Berry, 1995; Crafton, 2002; Cuthbertson \& Bridson, 2006; Grönoos, 1994; Gummesson, 1994; Kennedy, 2006; Li, Browne, \& Wetherbe, 2007). 
Over the past decade or so, the idea of managing customer relationships has been a top priority for marketers worldwide. Customer relationship management (CRM), the idea of fine-tuning the ways in which firms interact with customers, has required energy, focus, and investment in new tools and software to aid in the development of CRM systems. With the advent of the Internet, this idea has been extended into a Web-based business model and relies on e-business technologies to interact with, communicate to, and collect information from customers. This new evolved model is aptly termed electronic customer relationship management (eCRM). While eCRM is considered by many to hold even greater promise for business due to its digital foundation that enables greater data mining potential, it has yet to consistently deliver on its promise of facilitating better understanding of customer behavior (Adamson, Jones, \& Tapp, 2005; Bentum \& Stone, 2005; Q. Chen \& Chen, 2004; Fjermestad \& Romano, 2003; Jang, Hu, \& Bai, 2006; Li et al., 2007; Lin \& Huang, 2007).

The very nature of eCRM, with its many stakeholders, helps to illuminate the layers of complexity and their meaning with regard to what is intended by the idea of "informing" (Cohen, 2009). This complexity can be best understood by comparing eCRM to more "routine" informing systems which "tend to be driven by the skills of the designer" (Gill, 2009, p. 743). In contrast, the eCRM system central to this exploratory case study appears to be ever-changing as the interactions and needs of the varying stakeholder groups emerge. For example, "eCRM is too complex a concept to be comprehensively researched and efficiently classified merely by usual procedure and simple criteria" (Kevork \& Vrechopoulos, 2009, p. 62). Yet, research in this area rarely considers the views of all stakeholders involved in the phenomenon thereby rendering the complexity of eCRM into a seemingly routine construct. To effectively bridge this research divide requires consideration for all players involved in the phenomenon. It is the intent to inform all players that guides this research. Therefore, we embarked on an exploratory case study focused on a vanbased service franchise and motivated by the need to understand the perceptions and attitudes of all key stakeholders regarding the objectives of and motivations for implementing an eCRM program. The results of this study reveal important implications for the informing sciences including the need to balance human and computer interaction, issues related to control, the impact that "electronic" systems may have on marketing relationships, and the importance of balancing the interests and expectations of all stakeholders.

\section{Theoretical Framework}

To ground our line of inquiry, we adopt a theoretical lens that combines the perspectives of Stakeholder Theory (ST) and the literature base of Relationship Marketing (RM). We adopt this lens from (1) cross-disciplinary perusal of the literature in information systems, marketing, and management, (2) practical experiences, and (3) the apparent gap in the literature related to the inclusion of all key stakeholders in the eCRM phenomenon as a means of informing. Each of these will now be discussed.

One strand of eCRM research centers on systems development, IT aspects of implementation, and the benefits and value of customer data and data mining techniques for generating marketing intelligence and firm value. A second strand contemplates the human challenges that have plagued eCRM implementations and the means and methods for improving the success rate of eCRM system deployment. While value has come from previous research, there is a paucity of work considering the views of all stakeholders involved in the eCRM phenomenon and the complexity of the relationships between each stakeholder group. Considering the tenets of relationship marketing that are particularly prominent for service marketers and the importance of considering all involved stakeholders, we were compelled to adopt a theoretical lens that combines ST and RM to contextualize our research. 
The practical experiences of both authors led to the adoption of this theoretical lens. The first author spent more than 20 years at the executive level within franchise companies, primarily focused on franchisee operations and franchise consumer marketing. While much of the academic research in the area of franchising has employed the lens of agency theory (most likely due to the contractual underpinnings of the franchise relationship), in this author's experience the relationships between franchisor, franchisee, and consumers, rather than the franchise contract, are the key drivers of value creation within the respective franchise network. The second author spent more than 15 years researching, consulting, and working for Fortune 500 companies in the areas of process improvement, change management, and value creation. Although this author has little direct franchise experience, creating value is paramount to any business endeavor, including franchises, and is usually a direct result of focusing all involved stakeholders on achieving business objectives.

Adopting a lens with these two theoretical components, we are able address a gap in the literature by exploring the views, perceptions, and attitudes of all parties (stakeholders) involved in the design, development, and delivery of an eCRM system within a franchised network and how these findings relate to and add to the field of Informing Sciences. We now discuss the two components that comprise the lens, namely, ST and RM.

\section{Stakeholder Theory}

According to Freeman, ST at its simplest is about "...how people create value for each other" (2007, p. 11) and is a theory that considers what good management is. ST considers the context in which a business operates and recognizes that a firm's customers, suppliers, franchisees, investors, shareholders, employees, government agencies, and more all represent stakeholder groups of the firm. At its core, ST recognizes that business decisions are likely to affect one or more of its stakeholder groups, and thus a key assumption of ST is that values are necessarily and explicitly part of doing business (Freeman, Wicks, \& Parmar, 2004).

Traditionally, economists have stood in direct opposition to the edicts of ST. Their view is best understood by considering what is taught in relatively all US business schools: maximize shareholder value and safeguard shareholder assets. Through this perspective, one might conclude that if the goal is to maximize profit then the firm should try to maximize profit. From a ST perspective, this is unlikely to work, since if a business 'tries to maximize profits, in fact, profits don't get maximized, at least in the real world. The reason may be clear: tradeoffs are made in favor of financiers, and the tradeoffs are false ones due to complexity, uncertainty and bounded rationality" (Freeman, 2007, p. 11). In this same light, maximizing utility is central to rational decision models, yet "existing economic models of utility are plagued by many anomalies when applied to individual clients and also fail to incorporate many important features that are relevant to informing contexts" (Gill, 2008, p. 227).

To understand this more, consider the words of Donaldson, “... a stakeholder, such as an employee, must be granted intrinsic worth that is not derivative from the worth they create for others. Human beings have value in themselves. Their rights stand on their own. These rights themselves are morally and logically prior to the way in which respecting their rights may generate more productivity for others or the corporation" (2007, p. 19). Therefore, through the respect of stakeholder groups, the primary goal of the firm remains to maximize benefit.

To go one step further, Freeman et al. (2004) believe that ST is best understood by considering two conditions of the firm: (1) what is the purpose of the firm, and (2) what responsibility does management have to stakeholders. Through reflection, managers can determine what shared sense of value they create and how this value binds a core group of stakeholders together and, secondly, "what kinds of relationships managers want and need to create with their stakeholders to deliver 
on their purpose" (p. 11). ST rejects the notion that ethics and economics can be separated from a firm's values, purpose, and development of human relationships that lies at the heart of the franchising relationship above and beyond the simple contract that binds the parties together. One component that informs the lens through which we examine the project management implications of eCRM design, development, and delivery and the varying desires of each stakeholder group in the process is $\mathrm{ST}$. The second component is RM.

\section{Relationship Marketing}

The practice of marketing to new as well as existing customers to enhance the relationship between company and consumer has become commonplace. This phenomenon, called relationship marketing (RM), is particularly significant for services marketing because of "the maturing of services marketing with the emphasis on quality, increased recognition of potential benefits for the firm and the customer, and technological advances" (Berry, 1995, p. 236). This RM practice is commonly referred to as customer relationship management (CRM) and is rarely discussed without the additive construct of an Internet-oriented business model relying on e-business technologies with which to interact, communicate, and exchange information with customers and/or suppliers.

Similar to ST, RM is reliant on the consideration of all stakeholders' perspectives when designing, developing, and implementing new tools. With this multi-perspective ideal in mind, RM can be viewed as a paradigm shift for marketers who desire to move beyond a transactional approach toward more of a relational one (Grönoos, 1994; Gummesson, 1994). For purposes of this study, we adopt the definition of RM as "the concerns of attracting, developing, and retaining customer relations" (Berry \& Parasuraman, 1991, p. 3). In 2004, The American Marketing Association (AMA) changed its definition of marketing to, "Marketing is an organizational function and a set of processes for creating, communicating, and delivering value to customers and for managing customer relationships in ways that benefit the organization and its stakeholders" (AMA, 2008). Since that time, the concept of RM has become accepted as a more modern view of marketing (Harker \& Egan, 2006). Many marketing researchers proclaim that customers can no longer be viewed as being in endless supply and passive in regard to decision making - no longer can we take a "one size fits all" approach to the simple manipulation of McCarthy's (1960) 4Ps: Product, Price, Place, and Promotion, as has been the case for decades using a transactional approach to marketing.

\section{Literature Review}

Although eCRM research is prolific, there appears to be a lack of consistent understanding and agreement as to the operationalization of the term eCRM. Some research refers to eCRM as a philosophy (Crafton, 2002), some consider eCRM a marketing strategy (Bai, Hu, \& Jang, 2006), and others refer to specific software tools, methods, and systems as eCRM (H. M. Chen, Chen, \& Kazman, 2007; Scullin, Fjermestad, \& Romano, 2004). To complicate matters, in some instances, eCRM is differentiated as either analytical or operational (Fjermestad \& Romano, 2003; Swift, 2002). Analytical eCRM focuses on the collection and analysis of customer data, while operational eCRM focuses on all customer touch points throughout a transaction. For the purposes of this case study, we will use a definition of eCRM adapted from Berry \& Parasuraman's (1991) definition of relationship marketing - eCRM is a system with the purpose of aligning the firm 's planning, processes, and tools with the strategic intent of maintaining and enhancing the relationship between the firm and the customers it serves. This definition includes the additive ebusiness construct of a "system," and shifts the focus for eCRM to "maintaining and enhancing" the relationship with a firm's existing customers. 
While there is a great body of research on both CRM and eCRM, the eCRM literature can generally be classified into two strands: 1) the need to develop and nurture trust and loyalty in customer relationships, and 2) the best practices and methods for maximizing eCRM activities. Each of these will be discussed in more detail below.

\section{The Need to Develop and Nurture Trust and Loyalty}

The value of nurturing and developing a relationship between a firm and its customers is implicit in the marketing literature and is a generally agreed upon notion in the business world. At the center of such a relationship is trust, which research supports. Specifically, in an effort to encourage repeat purchases, capture a greater share of "wallet" (customer wealth), and improve the likelihood of referrals, many have recognized the role that trust must play (Bart, Shankar, Sultan, \& Urban, 2005; Chau, Hu, Lee, \& Au, 2006; Kim \& Tadisina, 2007; Porter \& Donthu, 2008; Walczuch \& Lundgren, 2004; Wang \& Emurian, 2005). Fostering a relationship that will ultimately create trust between parties is both intuitive and logical. Most literature in this area follows this intuition by employing a theoretical lens of relationship marketing and trust as a base. From this base, several models have been created, including the relationship generalization theory (Crosby $\&$ Stephens, 1987) and the progressive relationship building model (Kotler, Bowen \& Makens, 2003). However, the direct links from relationship $\rightarrow$ trust $\rightarrow$ repeat purchase intention $\rightarrow$ loyalty have been difficult to demonstrate empirically. As a relevant example, while it is generally recognized that a relationship of trust (versus a relationship without trust) is more likely to result in a customer recommending a firm to their friends and family, to encourage repeat purchases, and to result in customer retention, some findings show that recommendation intention alone is not a good predictor of a customer's future loyalty (Keiningham, Cooil, Aksoy, Andreassen, \& Weiner, 2007). This finding puts into question the direct link between satisfied customers referring the firm to another customer as a signal for future intention and will be a key element of investigation by our study.

\section{Best Practices for Maximizing eCRM Implementations}

\section{Leadership, culture and people issues}

From the literature, leadership is identified as a critical success factor for successful eCRM implementation. In a study by Q. Chen and Chen (2004), the researchers identify the need for initial management support as well as ongoing management leadership as demonstrated by consistent organizational commitment. This unwavering focus is necessary to ensure corporate alignment of the eCRM initiatives throughout all levels of the organization. Additional research considers the use of incentives and training as key factors for combating resistance from associates and managers who will be users of the eCRM system or tool (Q. Chen \& Chen, 2004; Fjermestad \& Romano, 2003). Moreover, a common issue in system failures was the lack of recognition for how much effect people could have on system success (Fjermestad \& Romano, 2003; Lin \& Huang, 2007).

Bentum and Stone (2005) support the positive role of effective leadership and highlight the need to align people and subcultures. Findings from this study refute the common claims by software vendors that there is a single path to CRM success. Instead, the authors suggest that there is "no single CRM culture that exists", but that a "communal and open corporate culture of communication" (p. 52) yields the best results.

Organizations with an existing offline culture of excellent customer care as demonstrated by service consciousness, a customer-centric organization, and customer-focused strategies are more likely to find eCRM success (Q. Chen \& Chen, 2004). As has been noted in previous research (Kennedy, 2006), those companies with distinct contact with customers, who are in very competi- 
tive market spaces, and who value differentiation for products and services are most ready for eCRM. However, the underlying corporate philosophy toward customers must also be present. Without an underlying commitment to customer care, a simple move from offline to online CRM practices will not improve a firm's relationship with its customers (Q. Chen \& Chen, 2004).

Strategic and thoughtful planning is also critical for eCRM success. Without a sound business strategy that links directly to the expected outcomes of eCRM, eCRM systems and tools are unlikely to succeed (Fjermestad \& Romano, 2003; Lin \& Huang, 2007). Strategic elements such as customer related benefits, the consolidation of customer information, and improved response times are all mentioned examples that must be carefully planned and designed in order to be realized (Lin \& Huang, 2007).

\section{Systems integration and data}

Systems integration and the alignment between business and information technology (IT) is another success factor prevalent in the literature. This factor is commonly defined as the matching of business processes with the IT architecture. The failure to achieve this match is one of the most cited reasons for eCRM failure (Q. Chen \& Chen, 2004; Lin \& Huang, 2007). While it is intuitive that the "system" must match the processes, integration issues have broad-reaching impacts. For instance, consideration for where data resides, the number of systems required for integration, the usability of and resistance to the system by users, and the expected outcomes and system functionality are commonly overlooked (Q. Chen \& Chen, 2004; Fjermestad \& Romano, 2003; Lin \& Huang, 2007; Padmanabhan \& Tuzhilin, 2003).

While "tight" system integration is identified as a critical success factor, a technology's ability to be flexible (Szmigin, Canning, \& Reppel, 2005) is also needed. Such flexibility allows the system to adapt to customer data and trends and, ultimately, to deliver the ability to personalize marketing information to customers. However, the ability to design, develop, and deliver usable, fully integrated systems is difficult. Understanding this, it is important to "continually measure and model customer sales, satisfaction and value, both in terms of absolute figures and trends" (Cuthbertson \&Bridson, 2006, p. 293) to ensure the system integrates with as well as improves the business. Research by Fjermestad and Romano (2003) points to the need for "....iterative, incremental approaches" (p. 589) for system design, integration, and implementation as a means to best address the aspects of usability and resistance.

The power of eCRM tools lies in the application of data and knowledge. For instance, the power is not found in the simple collection or mining of data, but rather in the means and methods by which the data is analyzed and applied to improve the relationship with customers. Therefore, knowing what to collect, how to collect it, and subsequently understanding how to use data is critical. Having a clear focus on what data you need and how you will use it to optimize the lifetime value of a customer is where the power of eCRM resides (Padmanabhan \& Tuzhilin, 2003).

This power is often created by a balance between human and computer interaction within eCRM implementations (H. M. Chen et al., 2007). In their study, H. M. Chen et al. reported that customer touch applications (e.g., intelligent system agents, human agents who can get "personal" and "social" with customers) were critical for repeat purchase intention and as a driver of loyalty. By balancing customer needs for both human and computer interaction, additional corporate benefits may be realized.

\section{Study Purpose and Research Question}

Although there is a great body of research on both CRM and eCRM, the authors have yet to discover any research that considers the perspective of all key stakeholders concerning eCRM implementation. Understanding the complex nature of human beings as decision makers and con- 
sumers, it comes as a surprise that so little research in this area has incorporated the voice of customers. We therefore embarked on an exploratory case study focused on a van-based service franchise and motivated by the need to understand the perceptions and attitudes of all key stakeholders regarding the objectives of and motivations for implementing an eCRM program. Franchise businesses are ideal for this type of exploration since franchisees serve the role of both service providers to their customers as well as customers to their franchisor.

\section{Design and Methodology}

\section{Selection of Case Company}

One of the fundamental roles of a franchisor is the support of their franchisees in marketing, training, and ongoing operational coaching. Many pundits within franchising attribute the higher success rate of franchise businesses versus those of independent entrepreneurs to franchisor support and training. For this case study we selected a US van-based service franchise for several reasons. First, the company has a long history of franchising success with over 30 years in the service business. The company has maintained a number one market share over competitors since inception, and the company is known for its proprietary equipment and solutions and is a market leader in new product development. Finally, this franchise has over 1,500 franchisees from coast to coast across the US as well as international franchise operations in over 50 countries.

This particular business format was selected since the key touch points with customers are primarily the franchisee marketing efforts, phone conversations between the customer and franchisee, and finally the interactions with the franchisees' in-home technician. Because there is no traditional brick-and-mortar location, the relationship between the firm and customer is built on these few touch points and not reliant on a specific location, signage, merchandising, or other elements present at traditional retail locations. Additionally, the lead author has direct experience with this company and prior to the study, served as the company's Vice President of Sales and Marketing.

Like many service based businesses, the keys for this company and its franchisees' marketing success rest with attracting new customers, maximizing sales revenue on each job, and keeping existing customers satisfied and returning. Of the keys above, management and franchisees believe that controlling the cost of new customer acquisition, which is typically done through traditional media channels such as direct mail, coupons, and yellow page advertising, can mean the difference between franchisee success and failure. In an effort to aid its franchisees with new customer acquisition, the franchisor regularly tests new marketing and advertising programs. The majority of these tests have historically been focused on direct mail with a special emphasis on the franchisees' database mailings and customer reminders. However, two key aspects of the business have changed resulting in a shift in marketing focus: the hiring of a new tech savvy Marketing Director and the diminishing effectiveness of traditional customer acquisition efforts such as yellow pages and marriage mail programs like Val-Pak and Advo.

These two factors (new Marketing Director and low return on traditional customer acquisition efforts) in combination have moved the marketing focus to more Web-based applications, and so, in late 2006, the company began redesigning its Website. The company's newly designed Website, which was launched in 2007, has common messaging and branding but also provides individual franchisee Web pages that allow for franchisee personalization and limited content control. During this redesign, the company began exploring new ways in which to drive Website maximization and search engine optimization. In fact, during this stage, very little new marketing was done by the franchisor that did not involve Internet applications. It was at this same time that the franchisor was approached by a new start-up company that had a vision to create an eCRM sys- 
tem specifically focused on service franchise systems. This software vendor made a presentation to a small group of senior executives at the franchisor headquarters and proposed the creation of a Web-based platform that would allow franchisees to garner feedback directly from their customers and encourage those customers most satisfied with the franchisees' service to recommend the brand to others. The software vendor argued that by having an electronic feedback and referral mechanism, the franchisor would have better customer data and marketing intelligence and the system would solve a key problem of many franchise companies - loyalty leakage or the need to keep all referrals "in the family." That is, many times a customer will recommend a friend or family member who lives outside the franchisees' licensed territory, but without an electronic means to capture such recommendations, more often than not, these leads are deemed worthless by the franchisee (since they cannot service the customer) and the lead is thereby lost. By capturing these leads electronically, they can be automatically forwarded to the franchisee who serves the area, thus reducing loyalty leakage within the franchise system.

While the concept was intriguing, senior management was skeptical. A few felt that it was difficult at best to create a brand connection with customers over the Internet. Another consideration of senior management was the opportunity costs involved and what customer risk might exist. To overcome these practical considerations, the software provider, whose primary objective was to secure a large well-known franchise company as a customer, agreed to develop a test system and evolve it based on company input at no cost. The only requirement of the franchise company was to actively promote the test system and (provided that the test system met expectations) promote a national rollout amongst its franchisees.

With these concessions in mind, the franchisor elected to begin testing this new program on a voluntary basis, with the objective of helping franchisees better manage the interactions with their customers via online means. The company told the software vendor that it would measure success by the number of referrals it received and the percentage of these referrals that resulted in a job for its franchisees. During the pilot phase, roughly 50 franchisees volunteered to participate and began testing the program with their customers.

\section{Research Method}

To investigate the attitudes and perceptions of all stakeholders in the process of implementing the newly designed eCRM tools, we chose the case study methodology (Yin, 2003). We focus on the experiences of the vendor, company, franchisees, and customers during the design, development, and ultimate testing of certain eCRM tools. In doing so, we study the phenomenon within its real context. To conduct this inquiry, we selected the president and founder of the eCRM vendor company as a participant (referred to as "vendor" in future instances). This vendor company is the only vendor providing eCRM tools for the case company and is a relatively young start-up company. In addition to the vendor, we selected three key managers within the franchise company to interview. We selected the CEO, CFO and Marketing Director (referred to as "a manager" in future references) since they are the only managers who participate in vendor selection and in the strategic planning for eCRM tool implementation.

\section{Selection of Participants}

The selection of franchisees was based on convenience sampling since we desired to select franchisees that are "cases within the case" (Denzin \& Lincoln, 2005, p. 451). We made our selection based on the following criteria: franchisees are currently involved with the eCRM pilot program, each has experience with online marketing activities, and each is considered to have some technical sophistication by the franchisor. Over a dozen franchisees were recommended to the researchers by the case company, and each was invited to participate via an email communication. Those who responded positively were called by the lead author to discuss the proposed study and to 
schedule an interview. All franchisees who agreed to participate were interviewed, and through these interviews the researchers reached saturation of insights (Denzin \& Lincoln, 2005). The franchisee participants in this study include six franchisees: two franchisees that have been in the franchise system for over 20 years, three with roughly ten years of experience, and one franchisee in his first full year of operation. Two of the franchisee participants run \$1 million franchise operations, three have businesses with roughly $\$ 500 \mathrm{~K}$ in annual revenues, and the newest franchisee's operation will do roughly $\$ 150 \mathrm{~K}$ in its first year. The franchisee participants operate their franchises in Florida, New Mexico, New Jersey, New York, Texas, and Washington. In future references, franchisees are referred to as "a franchisee."

Finally, the selection of customers was also based on convenience sampling. Customers were selected based on their frequent online purchase habits, technical sophistication, and willingness to participate. Of the three customer participants, two were female and one was male, with all being between the ages of 40-50 years of age. Company managers and franchisees also shared their perspective as consumers in addition to their company roles, providing additional insight from the consumers' perspective. In future references, customers are referred to as "a customer."

\section{Data Collection}

Data were collected in the spring of 2008 through initial interviews with each participant. In most cases, these interviews were conducted over the phone, but for local participants the interviews occurred face-to-face. Consistent with Glesne (2006), all interviews were approximately one hour in duration, conducted one-on-one, tape-recorded, and transcribed. In addition, to add to the trustworthiness of the data, member-checking interviews were conducted with each participant (Glesne, 2006) to ensure the accuracy of the interview transcript. In preparation for the memberchecking interview, the individual's interview transcription notes were emailed to each as a Microsoft Word document. Participants were asked to review the transcript thoroughly and encouraged to correct the document for any errors and to also include any additional thoughts by adding them to the document. Once the participant transcript review process was completed, an email exchange took place with each participant to finalize the member-checking interview process. In all cases, the transcript was verified by the participant and in four of the ten cases, material changes were made to the interview transcription file. The member-checking cycle occurred within 2-3 weeks of the initial interview and took place via email in all instances. In these ways, data were triangulated (Glesne, 2006).

\section{Data Analysis and Methods}

In addition to the interview and member-checking interview, all interview transcriptions and online communications of the participants were analyzed and coded, in accordance with traditional qualitative methods (Glesne, 2006). For purposes of this study, our coding techniques and paradigms relied on Strauss' systematic schema for coding qualitative data (Strauss \& Corbin, 1990). We adopted this coding schema because its systematic nature makes it easy for interested readers to see the codes that emerged from the data (for example, see the Appendix). Throughout the coding process, we recognize that the codes are based on our judgment and interpretation, and "limitations are consistent with the always partial state of knowing in social research" (Glesne, 2006, p. 169).

\section{Key Findings}

While the views, perceptions, and attitudes of each stakeholder group regarding eCRM are similar in some instances, there are other areas that are divergent and worthy of highlight. Interviews with each stakeholder combined both semi-structured interview questions as well as open-ended 
questions. Table 1 identifies the key expectations and interests by each stakeholder group that emerged from our coding of the data.

Table 1: Expectations and Interests for an eCRM System (Stratified by Stakeholder Group)

\begin{tabular}{|c|c|c|c|c|}
\hline & $\begin{array}{l}\text { What CRM } \\
\text { Means and key } \\
\text { eCRM Objectives }\end{array}$ & $\begin{array}{l}\text { How "e" impacts } \\
\text { stakeholder per- } \\
\text { ceptions of CRM }\end{array}$ & $\begin{array}{l}\text { Issues Related to } \\
\text { Control }\end{array}$ & $\begin{array}{l}\text { How Success is } \\
\text { Defined }\end{array}$ \\
\hline eCRM Vendor: & $\begin{array}{l}\text { System that cap- } \\
\text { tures all customer } \\
\text { data in single place } \\
\text { for use by franchi- } \\
\text { sor and/or brand } \\
\text { manager. }\end{array}$ & & $\begin{array}{l}\text { Fully integrated } \\
\text { system that cap- } \\
\text { tures all service- } \\
\text { specific leads, cus- } \\
\text { tomer feedback } \\
\text { and referrals. }\end{array}$ & $\begin{array}{l}\text { Own all "demand } \\
\text { touch points" like } \\
\text { call center, fran- } \\
\text { chisee point-of- } \\
\text { sale software and } \\
\text { electronic referral } \\
\text { system so leads are } \\
\text { captured by soft- } \\
\text { ware and sold for } \\
\text { fee. }\end{array}$ \\
\hline $\begin{array}{l}\text { Company } \\
\text { Management: }\end{array}$ & $\begin{array}{l}\text { A system to drive } \\
\text { incremental sales, } \\
\text { promotes the com- } \\
\text { pany image, ex- } \\
\text { change referrals } \\
\text { nationwide and } \\
\text { educate people as } \\
\text { to the benefits of } \\
\text { the brand. }\end{array}$ & $\begin{array}{l}\text { A system that cap- } \\
\text { tures all customer } \\
\text { data and allows } \\
\text { data mining and } \\
\text { "intelligent mar- } \\
\text { keting" initiatives. }\end{array}$ & & $\begin{array}{l}\text { A system that de- } \\
\text { livers referrals and } \\
\text { incremental jobs } \\
\text { for the franchise } \\
\text { network. }\end{array}$ \\
\hline Franchisees: & $\begin{array}{l}\text { A system that al- } \\
\text { lows personal and } \\
\text { relevant contact } \\
\text { and one that cap- } \\
\text { tures customer } \\
\text { feedback on our } \\
\text { service. }\end{array}$ & $\begin{array}{l}\text { A system to auto- } \\
\text { mate some of the } \\
\text { manual processes } \\
\text { like customer con- } \\
\text { firmation phone } \\
\text { calls and electronic } \\
\text { follow-up calls. }\end{array}$ & $\begin{array}{l}\text { A system with } \\
\text { acceptable use } \\
\text { agreements for } \\
\text { how data is kept, } \\
\text { used and owned. }\end{array}$ & $\begin{array}{l}\text { A system to help } \\
\text { retain existing cus- } \\
\text { tomers and gener- } \\
\text { ate new leads and } \\
\text { jobs. }\end{array}$ \\
\hline Customers: & $\begin{array}{l}\text { A system that al- } \\
\text { lows company to } \\
\text { market me in a } \\
\text { "personal" way by } \\
\text { knowing what I } \\
\text { like and need. } \\
\text { A system that al- } \\
\text { lows me easy ac- } \\
\text { cess to a person. }\end{array}$ & & $\begin{array}{l}\text { A system that } \\
\text { gives me informa- } \\
\text { tion so I can confi- } \\
\text { dently refer the } \\
\text { company to others. } \\
\text { A system giving } \\
\text { customer control } \\
\text { over frequency and } \\
\text { content. }\end{array}$ & $\begin{array}{l}\text { A system that ac- } \\
\text { knowledges my } \\
\text { past loyalty and } \\
\text { patronage and one } \\
\text { that rewards me. } \\
\text { A system that asks } \\
\text { for my opinion and } \\
\text { follows-up on what } \\
\text { I say. }\end{array}$ \\
\hline
\end{tabular}

Topics that were consistently mentioned within and between groups emerged as key "themes" of our data and are presented in the following section by these themes: (1) CRM - through the eyes of each stakeholder group, (2) how "electronic" impacts stakeholder perceptions of CRM, (3) is- 
sues related to control, and (4) the misalignment of stakeholder definitions of success. Each of these will be discussed in turn.

\section{CRM - Through the Eyes of Each Stakeholder}

\section{Creating a connection}

For comparison purposes, the first question in all participant interviews was simply, "Define what customer relationship management (CRM) means to you." A common notion for all stakeholder groups was the idea of CRM as a system or database to help retain existing customers and to acquire new ones: a description in line with previous research (Lin \& Huang, 2007). As expressed by the vendor, "We are dealing with a guy [franchisee business owner] in a truck with a cell phone and he cares about three things. He cares about getting new business, running his business and keeping his customers." The idea that CRM systems have a database at their core was articulately expressed by a customer:

I would think that CRM means for a business having some sort of a database of their customers so that they can manage all customer correspondence, order tracking, how any problems have been resolved, and how the company is building the relationship with their customers...

For franchisees and company management, the idea of CRM seemed to be more outwardly focused than inward. For instance, in the words of one manager, "It means to me how a company or organization interacts with its clientele over the long haul and puts together some means of contact that exists over time." Additional insight was provided by another manager:

The big part of it though, has to be just the spirit and attitude you convey about how you feel about the customer and how much you value them. Just the...image and attitude I guess they perceive about the company.

These comments suggest an "outbound" activity of communicating with customers in a manner that the company believes will create a connection and convey to the customer their importance. Complementing this outward focus seemed to be an almost synonymous understanding by franchisees of CRM and electronic marketing. While this was common thinking by most franchisees, it was best articulated by one franchisee when she described her idea of CRM as "managing the database online and managing the customers online and emailing the customers. Maybe shopping online via our Website or using our Website to help our customers." In this instance, the franchisee appears to be interchanging the notion of relationship building (managing the customers online) with the act of advertising to the customer (emailing customers), demonstrating the idea of CRM being perceived as more outwardly focused than inwardly. This is significant for two reasons. First, this outward focus implies less of an exchange between the franchisee and customer as would be expected from a relationship marketing perspective, and second, although the franchisee seems to be focused more on driving a transaction than enhancing a relationship, her words signify the care she has for the customer as a key stakeholder and driver of her own success. This idea suggests that the franchisee does see value in building a connection that will lead to repeat purchases and loyalty from the customer.

\section{Good relationships lead to loyalty}

While all groups articulated ideas related to customer interactions and the varying means of communication, only management and franchisees expressed this in linear terms regarding the relationship leading to something else; most notably loyalty. For instance, a manager said, "I like to think of the word loyalty, or loyalty programs as part of CRM systems... it is not just loyalty, 
it's about the basic relationship and then what else beyond there; the marketing relationship beyond just the basic relationship." In the words of a franchisee:

It is about the relationship with the customer...to ensure that we are holding our relationship with our customer very dearly and using all of the avenues that we have at our disposal to make sure that our customers remember that they love us...It [CRM] was a natural thing... understanding that we need to do a better job of staying in front of our customers and creating that relationship so they feel very loyal, they know us.

Interestingly, for customers, while the idea of having a good experience was important, in the minds of these consumers at least, it was more of a continuum. As expressed by one customer, "It $[\mathrm{CRM}]$ is just one of the various means of contact, as far as keeping the relationship between me and the company going." It is interesting to note that customers did not speak in terms of loyalty as an objective of a CRM system. While company management and franchisees used the word loyalty easily and consistently, not a single customer expressed the notion of loyalty when defining what CRM might mean. In fact, customer descriptions were very utilitarian and transaction based. This finding is in line with previous research that found the concept of customer loyalty not something that consumers recognize, and, when distilled to its simplest definition, loyalty might be viewed as simply whether or not the customer will make a repeat purchase (Pitta, Franzak, \& Fowler, 2006). However for franchisees and company management, the concept of loyalty included the likelihood of repeat purchasing, for instance, "To keep my customers where they belong in my database and not going anywhere else," as one franchisee expressed. Additionally franchisees associated response rates for advertising, quality feedback scores, and customers' likelihood to recommend the service to friends and family as another aspect of loyalty. This was best expressed by another franchisee, "Having them bringing us referrals, like their friends or family that might be good prospects for us." One manager articulated the idea like this, "[To keep] the end customer loyal to us and make it hard for them to switch [service providers]." This is interesting to consider since it appears that both management and the franchisees are in alignment regarding this linear progression with customers. Meaning, satisfy the customer and the customer will "repay you" in terms of repeat purchases and referrals. For customers, while none spoke in terms of loyalty directly, they all did indicate a desire to remain loyal to companies they have had a good experience with. For instance one customer said,

[The company] is always in tune in working with me and doing a good job for me, so I won't test a cheaper one [company] because it seems risky to switch, because you don't know what you are going to get... the quality, I mean everything looks good in a picture [laughing]. So they [the company] have a good way of once you started working with them, they'll continue to work with you well to keep you coming back...

This statement was indicative of the views expressed by all customers in this study - make the experience a good one so that they don't have to find another option. They prefer to remain "loyal" as long as the exchange remains positive and fair.

\section{Loyalty equals repeat purchases}

As interviews progressed with the vendor, company management, and franchisees, aspects related to building the relationship with customers shifted into the area of analysis of the customer relationship. That is, the notions expressed moved from ideas related to giving the customer reasons to be satisfied with the relationship to getting the customers to do something such as providing information or recommendations and referrals. As expressed by a manager, "eCRM is using that [customer information] for an additional relationship...I want to sell you something else. I want to market to your friends and neighbors and seek referrals." In the words of the vendor: 
For eCRM, when it comes to analyzing the customers, here's what we need to know: Are they happy or are they not happy? If they are not happy, why not? If they are happy, then let's try and find the way to get them to tell their neighbor or tell their friends that you did a good job and give them an easy way to come back and make a recommendation. Collect some information in such a way that I get a message on my phone, or an email or both that says, Mrs. Smith recommended Mrs. Brown and Mrs. Brown wants to give a referral.

For franchisees, while the majority indicated a desire to seek referrals from existing customers, most seemed more focused on the information they could receive from customers to help them improve their service. For instance, one franchisee said it this way, "A huge pro for me is that we are maintaining our quality, we are finding out what our customers think about us. It is an easy way to see trends." Another said,

The primary reason [for the eCRM] system is to give the customer a good impression or good feeling of service and bring the customer back to us through us gaining knowledge of them, you know what they like, what they don't like, and as we learn more about our customer it is easier to bring that customer back to us.

At the core of these comments is the assumption that once a transaction is complete and the customer has provided positive feedback, repeat purchases are likely.

\section{Repeat purchases don't always lead to referrals}

In addition to repeat purchases, there is great hope that a satisfied customer is willing to promote the company's business amongst friends and family. For the customers in this study at least, even when completely satisfied with a company, they expressed concern regarding giving referrals and recommendations. This implies that there is more being evaluated by the customer than simply the customer's assessment of the core product and/or service exchange. That is, research has identified security, privacy, and consumer protection as some of the most important issues with respect to e-business (Eastlick, Lotz, \& Warrington, 2006; Walczuch \& Lundgren, 2004). As one customer expressed, "If I am going to give them [the company] people's names or information, I would want to understand what is going to happen and feel comfortable with what they are going to do from there." For another customer, "I am not sure I really want to name all my friends to a company or store...it's not totally comfortable to me, so I suppose you would have to get their permission." In fact, all customers expressed issues related to security, privacy, and the use of their personal information.

\section{How "Electronic" Impacts Stakeholder Perceptions of CRM}

As a follow-up question, all stakeholders were asked if the word "electronic" attached to CRM changed the meaning for them. It was at this juncture that the notion of eCRM diverged in meaning based on the stakeholder group in question. For customers, the idea of eCRM was really no different than traditional CRM. As one customer articulated:

I would assume that, especially in this day and age, it is always electronic at least as it is some kind of a database or data store on computers, so at least to that extent, I would assume that it is electronic anyway, so it doesn't really change my notion of eCRM.

However, for company managers, doubt and skepticism emerged over the ability to maintain an emotional connection between customer and firm via electronic means. 


\section{Loss of emotional connection}

In responding to how eCRM differed from CRM, company management expressed their perceptions in relation to what eCRM was not. For instance, one manager expressed this well, "If you want customer relationship management you build a lot of emotional connection. Because if you think it is about something functional, tactical, or technical, you are crazy." Another manager said, "Well the first reaction is that electronic takes all the emotion out of it." This manager went on to say:

It is a matter of risk, reward, and payback. Certainly anything that has payback and promotes a positive image as opposed to irritating [customers]...there are so many spams these days it is getting increasingly difficult for anyone to get attention strictly off the internet with blind mailings or even in the case of the vendor's solution which is highly targeted...

These statements imply that management perceives risk in the implementation of an eCRM system versus continuing with the more traditional marketing programs that the franchise network has employed for over 30 years.

However, franchisees appeared to be more open to this new electronic channel for enhancing customer relations and continued to interchange the term eCRM with electronic marketing. For instance, one franchisee said, "If they book online and are already accustomed to doing stuff online, why not keep them that way?" Another franchise said, "At this point, [eCRM] would supplement my marketing, but down the road, I am a tree hugger, I would rather send out an email than send out a thousand postcards." And another said:

The electronic part means, essentially to me at least, doing the same thing but doing it more automated. So setting up the criteria, setting up the emails, you are using newsletters, special offers... maybe you set up a program for the year and flip it on autopilot and the only time you ever need to mess with it is to make adjustments and you get all your customers emails and they call you and you make lots of money [laughing].

The franchisees' shift in perspective is interesting and leads one to wonder whether the eCRM system in development is simply viewed as an outbound exchange mechanism for franchisee advertising, or if interaction, which by definition signifies information moving both to and from receiver and sender, is being contemplated. For customers, while the idea of having more communication take place online was not initially problematic, all did express the desire for an easy way to also connect with a live person.

\section{Need for human accessibility}

The idea of human interaction and accessibility as part of an eCRM system was mentioned by all customers as an important component of any eCRM system and this idea exposed the greatest gulf of understanding between stakeholders. In recent years, relationship marketing literature has begun to consider the relational benefits a customer receives during an exchange as a separate component from the core product or service exchange. Additionally, these relational aspects have been found to be relevant in online selling environments much the same way as they are in a traditional face-to-face context (Yen \& Gwinner, 2003). One customer expressed this articulately:

You know, we don't live in a perfect world obviously, so often times issues arise. It could be an issue with a product having damage in shipping, or various reasons why things don't go the way they should and you need to have somebody you can talk to who can address your issues. So that is important to me. So I would not buy from somebody if I couldn't talk to somebody or settle an issue. If there is no human contact then, it is like you're dealing with a vending machine. 
While expressing what was important when conducting business online, another customer said, “...Fast response times, delivering on what is promised, good return policies, warranties, accessibility. That is one problem I have found is accessibility, actually if you need to contact a live person sometimes that can be pretty difficult to do." And another said, "I really still think that personal contact, the person-to-person relationship, you cannot replace that."

It appears from these comments that customers highly value the "personal touch" and while not inherently opposed to online communications and interactions, accessibility to a live person remains a priority.

\section{Automating the relationship}

For the vendor, and particularly franchisees, once the notion of a system for eCRM was in the discussion, something interesting began to occur. Conversations shifted from aspects of relationship marketing to dialogue heavy with technology, automation, and streamlined electronic marketing efforts like email blasts, automated confirmation calls to customers, electronic quality surveys, and personalized customer landing pages on the franchisees' Websites. Considering that consumer commitment to online businesses may be more difficult to establish and less likely to persist than in traditional businesses (Li et al., 2007), this shift from the personal to the automated was surprising. In the words of one franchisee, "I would like for us with our huge email database, to be able to target to them [customers] specials for their needs." Another franchisee echoed this same line of thinking, "One day I hope that we can do enough with our database and our email marketing that everything that we have, everything that we do, has our Website on it...so hopefully in 2-3 years, that is the way we are going to market our business." What at first was conversation about building a one-on-one relationship with a customer now became more focused on the franchisee's database of customers as a single entity and how the eCRM system needed to personalize communications with customers in an automated fashion.

These notions stand in direct contrast to what the customers in this exploratory study reported wanting: specifically, an easy way to connect with a person during the purchase cycle. In the words of one customer, "I think that when you talk to somebody, at least to me, I become friendly with them if they are nice people and you know, I think, I would buy from them again and recommend them." The customer continued:

Even if you have just that one time of human interaction, it just gives you a sense of confidence with the company that once you have that confidence with the company that you are buying from, you can just deal with the website and just buy and know that things will go smooth.

Considering that customers expressed a need for human accessibility for both a measure of company credibility and as a means to resolve problems, it appears that customers view human accessibility as a component of any eCRM system - an idea that should not be overshadowed by the sizzle of the underlying technology or the promise that data mining might hold.

\section{Issues Related to Control}

For customers, lack of control was a key theme, and customers consistently referred to a lack of control regarding the frequency and content of communications.

\section{Mailbox vs. inbox}

In discussing their attitudes regarding the solicitation these customers receive from companies, one customer said, "I tend to uncheck those boxes that say do you want to get offers from us because I don't want my email inbox to be flooded with that kind of stuff. And it seems like they really go overboard." Another customer expressed a similar sentiment, "When they [companies] 
start pushing things, and start saying you have to buy this product if you bought this one because it is worthless without the other. I think, well I'm not gonna buy anything." While all customers indicated a preference for receiving marketing solicitation in their inbox versus their mailbox, it was for two primary reasons: either because electronic messages are easy to delete or they felt some environmental concern for so many catalogs being thrown away. One customer expressed guilt, "If you get a catalog, you almost feel guilty if you throw it away, you look at it and think, wow that is a lot of paper." Another said, "I feel like I am just throwing stuff away and deleting stuff all the time and it is like, what a waste of paper." And another explained in more detail why she also preferred inbox versus mailbox solicitations and shared her strategy for handling the massive amounts of marketing information:

If I had to get it, if I couldn't suppress getting it, I would rather get it in my inbox in email because there are a lot of tricks you can do. You can set up a bogus Gmail or hotmail email account and have all of these solicitations go there and never look at it. Or you can, you know it is so easy to delete at least you don't have to deal with the physical ads, and the landfill.

\section{Matching frequency to purchase cycle}

To counter this, all customers in this study believed that the frequency of solicitation should match the frequency of purchase. One customer expressed the idea eloquently, "I guess whatever it is that you are selling or what your service is, if it's something you may purchase maybe twice a year, then the frequency of contact should match." Additionally, customers believed that by giving more control over the content and frequency of solicitation, that the effectiveness of solicitation may improve. For instance, one customer said, "I think that sometimes you get so much stuff that you sort of become numb to it and so frequency, less frequent might be more powerful." While all customers mentioned a desire for having a way to control what they received and how often it came, it was with cautious optimism. Most expressed skepticism that a company would be willing to send fewer solicitations or put more control in the hands of the customer. One customer summed this thought up well:

I think there is an element of marketing that is about creating the market and you cannot create a market if you let people say I only want to see X, Y, and Z. To create a market, you also need to show them A, B and C too. So I feel skeptical to think a company would implement those types of programs and let the customer have control over what they are going to see.

The irony here of course is that by "force feeding" customers with either too many solicitations or with the wrong content, the effectiveness of the advertising may become limited.

\section{Keeping control of the data}

For the company and its franchisees, different concerns over control emerged than those expressed by customers. Primarily, the control factors most significant to these stakeholders had to do with two areas: content and image of messaging, and database control issues. As is common in franchisor/franchisee relationships, issues surrounding the brand and image were paramount to the franchisor. In the words of one manager, "As a franchisor, controlling the message outweighs the creativity... it would be a mistake to give a franchisee free rein without some control or parameter regarding what is being said to the customer." However, for franchisees, issues around the control of data were more important. This is a key issue since the customer data and databases reside at the local franchisee level. While the franchisor has a right to audit and even collect a franchisee's customer data, to date, the franchisor in this study has typically only exercised this right when a franchise terminates. To franchisees, their customer database is the single most valu- 
able asset in their business, so it comes as no surprise when we glimpse the sensitivity of the issue in the words of one franchisee:

I know that there are some people that would probably feel uneasy if it [eCRM] was completely automated since they wouldn't know what data is being extracted. I would want a clear contract with whoever my vendor is before I let them into my database and give them access to it. I would want to get contracts and want to know what they are taking and when they are taking it and how they would be using the data.

In fact, this sentiment was voiced in similar terms by most franchisees in this study. Knowing that the system under test is a Web-based application with the data stored on the vendor's server, questions related to acceptable use standards and data ownership and access are clearly needed. In fact, data and system integration is one of the most cited reasons for eCRM failure (Lin \& Huang, 2007). Considering this, it was surprising how lightly the issues of data control and access were considered by the vendor. For instance, "[With my eCRM system] You don't need to call the customer back and say 'how about 3pm?' it [eCRM system] will do it automatically because the software will have the integrated calendars and know when the franchise is able to do the job." While the vendor's "vision" for the system is intuitive on the surface, assumptions regarding his access to the franchisee's data and use thereof are apparent in the vendor's statement. As further demonstration of the gap that exists in the perceived issues surrounding data and data use, the vendor goes on to describe another key benefit of his eCRM system:

These small and medium sized business entities, they've got these $\$ 100$ or $\$ 200$ million dollar brands and they haven't got a clue who their customers are, no idea. And that is because their customers are residing in the computers of each of the individual franchises. My system gives them this data.

This comment again highlights the vendor's belief that he will have full access to all franchisee data and free rein in regard to its use. To consider how difficult this might actually be, consider that the franchisor does not currently have access to the franchisee's data. However, without full data access, the vendor's vision for his system is not feasible.

Interestingly, similar to findings in other research (Q. Chen \& Chen, 2004; Crafton, 2002; Lin \& Huang, 2007), the franchisee participants in this study believe that full integration with their own computer systems and marketing programs is a critical success factor for eCRM success. Yet, issues related to data and its access represents perhaps the biggest obstacle to full eCRM implementation. To put this into perspective, franchisees do in fact control their own database of customers. The systems used by franchisees vary with no current requirement in place for franchisees to share or upload this data to the franchisor. Thus, the customers that represent this company's $\$ 300$ million dollar brand are in fact residing in thousands of PCs across the US. Although franchisees want system integration to ease the burden of manual uploads and time consuming management of e-marketing activities, to do so requires a common commitment and finesse on the part of all stakeholders.

\section{The Misalignment of Stakeholder Definitions of Success}

While it might appear that the franchisor and vendor share a common set of motivations and desire for central integration, a surprising undercurrent of conflicting priorities, objectives, and interests emerged through our data collection process. For the franchisor, the driving force is the mission statement of the company as expressed by one manager, "We seek our success by seeking our franchisees' success" - a mission that indicates a belief in the notion that by managing based on consideration of all stakeholders, performance for all stakeholders will be better. This stakeholder view considers the "joint successes" of franchisor, franchisees, and customers as the fundamental partners in the exchange. 


\section{Control and leverage}

In contrast, the vendor appears to have an alternative and previously unspoken mission at play that is independent of franchisor or franchisee success. This was best expressed in the vendor's own words:

So if somebody is to search your service in Dallas, that search term should actually create a lead for you in Dallas, but what I see is that it would create a lead for every service provider in Dallas and then we would aggregate all those leads together and approach all the service providers and see who will pay for them.

Considering this comment by the vendor, we can glimpse his desire for control and leverage of all leads that can be sold (by him) to the highest bidder for his own benefit. This comment suggests that the vendor is operating without due consideration for the other stakeholders in this scenario and is working to maximize his own value and benefit potentially at the cost of the other stakeholders. Not only does this comment uncover the self-interest at play with the vendor, but also points to the transactional nature of his eCRM system. Meaning, by developing a system that captures all leads, he can focus on selling these leads to the highest bidder (which may be outside the franchise network of this case study) rather than developing long-term relationships with the franchise company and its franchisees. This is in direct contrast with the initial eCRM goal of the company and franchisees to develop a system to capture feedback from customers and secure new leads and referrals.

This finding prompts us to question whether issues related to data and control can be remedied. As discussed earlier, our data suggest that all stakeholder groups, with the exception of the vendor, expressed concern over data sharing and access. Customers in this study focus on privacy and the use of their personal information by the company. In contrast, franchisees and management focus on safeguarding their respective assets (i.e. data). Recognizing that the customer database for each franchise, and collectively for the brand overall, represents the greatest asset the company owns, one might question why issues related to data and the negotiation of acceptable use agreements are still being raised after the launch of the pilot program.

From our conversations with participants, it appears that the vendor has changed course since the launch was approved. Company management and franchisees are only aware of the original plan for an eCRM system that would initially launch as an Internet referral and feedback mechanism. However, the vendor has evolved his vision to include the integration of all customer touch points, such as Web advertising, call center operations, franchisee point-of-sale systems, and lead management tools, in an effort to capture all service specific lead sources - a view that goes far beyond the approved launch of the eCRM test system. As mentioned previously, integrating systems is crucial for eCRM system success, yet the fundamental questions related to data control and integration remain unasked and unanswered.

What is most notable is that the views of customers, franchisees, and company management are fairly well in sync; however, the vendor seems to be operating independently.

\section{Managerial Implications}

There are a number of potential implications that emerge from the data related to effectively designing, developing, and ultimately deploying an eCRM system. Specifically, (1) balancing human and computer interaction is critical, (2) the aspects of control are varied and at times can be conflicting for each stakeholder group, (3) balancing interests and expectations is complex, and (4) be wary of the "free lunch" syndrome. Each of these will be discussed in more detail below. 


\section{Balancing Human and Computer Interaction}

From the data, it appears that the word "electronic" has a powerful pull on the perception of how customer relationship management might be accomplished. This is particularly relevant for the informing sciences since each stakeholder group views their "client" as unique. For instance, the vendor was commissioned by the franchisor, thus the franchisor is the vendor's client. The franchisor considers the franchisee the client and the franchisee views the end customer as client. Dependent on what each stakeholder "chooses" to share with their clients and the motivation and inherent desire to be informed by the various clients, the balance for computer and human interaction may be impacted.

For the participants in this study, it was difficult, if not impossible, to balance the aspects of building relationships with the cost savings associated with streamlined transactions and automated e-marketing. In essence, the power of the one-to-one relationship seemed easily converted into an exchange between customer and company computer. While customers do in fact value the benefits of electronic exchange (Porter \& Donthu, 2008), those in this study believe the benefits of combining human interaction and accessibility with electronic systems outweigh a purely electronic exchange. This is understandable considering that e-marketing, automated confirmation calls, and Web-based surveys are likely to hold more value for a company than for its customers. Research has shown that integrating personal contact with select customers can be valuable and increase company profits (Pitta et al., 2006). This type of integration can strengthen a firm's offering and is supported by previous studies purporting that eCRM is much broader than simply a technology (Q. Chen \& Chen, 2004; Crafton, 2002; Fjermestad \& Romano, 2003; Kennedy, 2006). Based on the input from stakeholders in this study, the data suggests that eCRM systems built without an eye for human interaction should be rethought.

\section{Recognize Aspects of Control are Varied and can be Conflicting}

With the exception of the vendor, the data suggests that each stakeholder group has concerns regarding customer data and its use. One might argue that the concerns of the customer really are the same as those of the franchisee or company management: that of security, privacy, and how customer data will be used (Eastlick et al., 2006; Salmen \& Muir, 2003). In essence, the customer data belongs to the customer and is simply on loan to the company and its franchisees. This is a mutual exchange intended to provide the parties with a means in which to serve and be served. However, the competing interests of the vendor regarding more integration and control of the leads as a revenue opportunity may threaten the balance of a mutual exchange. This conflict, viewed through the perspective of the informing sciences, raises doubt regarding what information the vendor will share and how he will share it. Considering that data access and its use is paramount for a fully-functioning eCRM system, information and the act of informing becomes a key aspect of the design, development, and ultimately delivery of the system. Therefore, issues such as data storage agreements, acceptable use agreements, and other rules of engagement should be drafted with consideration for what the company's greatest asset is and how it should be protected and not be based solely on the vision of the vendor.

\section{Balancing Interests and Expectations}

Scoping the system with all stakeholders in mind is both intuitive and supported in the literature (Fjermestad \& Romano, 2003; Lin \& Huang, 2007). However, from the standpoint of informing sciences, it is difficult to execute. With technology-driven innovation, not all stakeholder groups tend to be equally knowledgeable or informed. In our case, the vendor appears to be the 'expert' in the room regarding system design, development, and delivery, yet is operating with a divergent "blueprint" of the final system when compared to that of the company, franchisees, or customers. For instance, while three of four stakeholder groups seem to be relatively in sync (with respect to 
our case study), the vendor is not. In spite of the fact that the design of this system began with a common goal and vision for the outcome, the data suggests that the divergence of goals and expectations has increased over time. While franchisees and company management are still operating under the assumption that the eCRM system will deliver what was originally contemplated during launch discussions, it appears that the vendor is now working toward alternative outcomes. The lesson here is to continue design, outcome, and expectation discussions during an entire project, not just during initial planning phases. While interests and expectations will at times be conflicting, by communicating openly and frequently, the probability for chronic misalignment of interests and expectations is likely to be reduced.

Additionally, based on our lens of ST and RM, customer viewpoints should be more central to the design and development of customer/company tools. Specifically, the customer data from this study suggests a few guidelines that management should consider when designing eCRM systems:

1. Disclose how information will be used from referrals provided.

2. Allow easy access to a human in addition to electronic communication channels.

3. Match a product's buying cycle with the frequency of solicitation.

4. Allow choice for inbox v. mailbox solicitation.

5. Reward loyalty.

If the goal of a program is loyalty and repeat purchases from customers, it makes sense to start with the customer's interests and needs first. From there, as you move "up the channel" from customer to franchisee, to franchisor, to vendor, work to ensure that each new requirement does not "cancel out" one from a previous stakeholder group. When there is conflict or competing interests, evaluate these on a case-by-case basis without instituting overarching decision making that determines the hierarchy by stakeholder group. Meaning, franchisees' interests should not always override those of customers, nor should franchisors' interests always override those of franchisees. Each point of conflict must be evaluated on its own merits. Finally, in line with this process, the vendor should be given explicit directions for the design, development, and delivery of the system and, by delivering to specification, the vendor should be able to maximize his own benefits as well.

\section{Be Wary of the "Free Lunch" Syndrome}

Considering that the launch, design, coding, and system training have been shouldered by the vendor without any compensation from the company, one might argue that the vendor feels justifiably free to modify the design and intention of the system as he sees fit. While in-depth discussions did occur in regard to all issues related to the system, this was over one year ago when the launch was first considered. Since then, the vendor has been actively recruiting other franchise companies and, according to the vendor, has driven use and adoption much faster at those other companies than at the company in this case study. Compounding this conflict of interest, it also appears that the eCRM system under test has been created with more consideration for the underlying technology than the customer - an experiential outcome common with IT-led eCRM initiatives (Adamson et al., 2005). While the company may have saved out-of-pocket development costs, the control and influence they have given up may have cost more in lost opportunity than initially foreseen.

\section{Limitations and Future Research}

This research is limited by the general nature of case-based research. This study is not meant to infer generalizability to the entire franchising space or any other defined system. It is simply intended to shed light on the issues surrounding third-party developed eCRM systems and the vary- 
ing objectives and issues each stakeholder group claims. However, the issues, recommendations, and suggestions we offer in this case are grounded in the data and thereby provide a rich and valuable source of information that can be trusted for the case company in particular. That is, what the case company faced in terms of differing objectives and goals with an eCRM vendor was what actually happened and can happen in other organizations.

Understanding the limitations of this case study, specifically the limited number of participants, questions remain. For instance, would other customers share the beliefs and attitudes of eCRM innovation as expressed by the participants here? Would franchise management and franchisees from other van-based service companies share these same beliefs and attitudes? How is the orientation of eCRM vendors (off-the-shelf packages) different than vendors supplying new development? Are the orientations of in-house IT developers the same or different than the views expressed by this vendor? Because one or more key stakeholder groups have been absent in previous research efforts, we believe there is rich opportunity for additional insight into the perceptions and attitudes of all stakeholders during the design, development, and delivery phases of eCRM projects.

\section{Conclusion}

The value of nurturing and developing a relationship between a firm and its customers is implicit in the marketing literature and is a generally agreed upon notion in the business world. Understanding that trust is at the center of such a relationship, building relationships over time is important for companies as even a slight increase in customer retention can have a significant impact on corporate profits (Cuthbertson \& Bridson, 2006). Understandably, many companies look to eCRM as a method for developing a relationship $\rightarrow$ trust $\rightarrow$ repeat purchase intention $\rightarrow$ loyalty paradigm. However, with the informing "breakdowns" viewed in this case, the system's ability to be useful in real-world informing may be limited. While we know that customers value the opportunity, choice, and convenience of electronic transactions, they count on human interaction to solve problems and provide a more personal exchange. For this reason and as previous research has shown, eCRM is a valuable component of relationship marketing and can increase the financial performance of firms (Jang et al., 2006). However, a component in isolation is unlikely to fully maximize benefits and effectively inform across channels and stakeholder groups.

As previous research has shown, as well as the lessons provided by this case study, aspects related to both human and systems issues are critical considerations on the journey to eCRM success. From a practical standpoint, this case study illuminates the challenges of managing a vendor with a strong, yet narrow specialization. For these reasons, we encourage companies to consider the feel and emotion that the customer/firm relationship should evoke. Doing so can inform a company in the design, development, and implementation of an eCRM system. For it is not just software and systems at stake, but well-designed and thoughtful human protocols for contact between firm and customer that will nurture and strengthen the relationship that binds all stakeholders.

This case study has presented some pitfalls and benefits of eCRM design, development, and implementation that may well inform others who follow. Understanding the desires and expectations of each stakeholder group is a key ingredient in the eCRM recipe. While systems and their data mining capabilities hold great promise, remember that the system, processes, and tools are about building relationships, which is best done with the customer at the core of everything we do. 


\section{References}

Adamson, G., Jones, W., \& Tapp, A. (2005). From CRM to FRM: Applying CRM in the football industry. Database Marketing \& Customer Strategy Management, 13, 156-172.

AMA. (2008). American Marketing Association Web site. Retrieved October 23, 2008 from http://www.marketingpower.com/_layouts/Dictionary.aspx?dLetter=M

Bai, B., Hu, C., \& Jang, S. (2006). Examining e-relationship marketing features on hotel Websites. Journal of Travel \& Tourism Marketing, 21, 33-48.

Bart, Y., Shankar, V., Sultan, F., \& Urban, G. L. (2005). Are the drivers and role of online trust the same for all web sites and consumers? A large-scale exploratory empirical study. Journal of Marketing, 69, $133-152$.

Bentum, R. V., \& Stone, M. (2005). Customer relationship management and the impact of corporate culture - A European study. Database Marketing \& Customer Strategy Management, 13, 28-54.

Berry, L. L. (1995). Relationship marketing of services: Growing interest, emerging perspectives. Journal of the Academy of Marketing Science, 23, 236-245.

Berry, L. L., \& Parasuraman, A. (1991). Marketing services: Competing through quality. The Free Press.

Chau, P. Y. K., Hu, P. J., Lee, B. L. P., \& Au, A. K. K. (2006). Examining customers trust in online vendors and their dropout decisions: An empirical study. Electronic Commerce Research and Applications, 6, 171-182.

Chen, Q., \& Chen, H. M. (2004). Exploring the success factors of eCRM strategies in practice. Database Marketing \& Customer Strategy Management, 11, 333-343.

Chen, H. M., Chen, Q., \& Kazman, R. (2007). The affective and cognitive impacts of perceived touch on online customers' intention to return in the web-based eCRM environment. Journal of Electronic Commerce in Organizations, 5, 69-91.

Cohen, E. B. (2009). A philosophy of informing science. Informing Science: the International Journal of an Emerging Transdiscipline, 12, 1-15. Retrieved from http://inform.nu/Articles/Vol12/ISJv12p001015Cohen399.pdf

Crafton, T. W. (2002). Do you really know your customers? Strategic Finance, October, 55-57.

Crosby, L. A., \& Stephens, N. (1987). Effects of relationship marketing on satisfaction, retention and prices in the life insurance industry. Journal of Marketing Research, 24, 404-411.

Cuthbertson, R. W., \& Bridson, K. (2006). Online retail loyalty strategies. International Journal of Information Technology and Management, 5, 279-294.

Denzin, N. K., \& Lincoln, Y. S. (2005). The sage handbook of qualitative research, (3rd ed.). Thousand Oaks, CA: Sage Publications.

Donaldson, T. (2007). Two Stories. Proceedings of the 2007Academy of Management, Symposium on the Future of Stakeholder Theorizing (pp. 16-20). Retrieved from http://www.ronaldmitchell.org/publications/BEQ07.pdf

Eastlick, M. A., Lotz, S. L., \& Warrington, P. (2006). Understanding online B-to-C relationships: An integrated model of privacy concerns, trust, and commitment. Journal of Business Research, 59, 877-886.

Fjermestad, J., \& Romano, N. C., Jr. (2003). Electronic customer relationship management. Revisiting the general principles of usability and resistance - An integrative implementation framework. Business Process Management Journal, 9, 572-591.

Freeman, E. R. (2007). Ending the so-called 'Friedman-Freeman' debate. Proceedings of the 2007Academy of Management, Symposium on the Future of Stakeholder Theorizing (pp. 7-12). Retrieved from http://www.ronaldmitchell.org/publications/BEQ07.pdf 
Freeman, E. R., Wicks, A. C., \& Parmar, B. (2004). Stakeholder theory and 'the corporate objective revisited'. Organization Science, 15, 364-369.

Gill, T. G. (2008). A psychologically plausible goal-based utility function. Informing Science: the International Journal of an Emerging Transdiscipline, 11, 227-252. Retrieved from http://inform.nu/Articles/Vol11/ISJv11p227-252Gill220.pdf

Gill, T. G. (2009). Chapter 22: Routine vs. non-routine informing: Reflections on what I have learned. In Gill, T. G. \& Cohen, E. (Eds.) Foundations of informing science (pp. 739-766). Santa Rosa, CA: Informing Science Press.

Glesne, C. (2006). Becoming qualitative researchers ( ${ }^{\text {rd }}$ ed.). Boston: Pearson Education, Inc.

Grönoos, C. (1994). From marketing mix to relationship marketing: Towards a paradigm shift in marketing. Management Decision, 32, 4-20.

Gummesson, E. (1994). Making relationship marketing operational. International Journal of Service Industry Management, 5, 5-20.

Harker, M. J., \& Egan, J. (2006). The past, present and future of relationship marketing. Journal of Marketing Management, 22, 215-242.

Jang, S., Hu, C., \& Bai, B. (2006). A canonical correlation analysis of e-relationship marketing and hotel financial performance. Tourism and Hospitality Research, 6, 241-250.

Keiningham, T. L., Cooil, B., Aksoy, L., Andreassen, T. W., \& Weiner, J. (2007). The value of different customer satisfaction and loyalty metrics in predicting customer retention, recommendation, and shareof-wallet. Managing Service Quality, 17, 361-384.

Kennedy, A. (2006). Electronic customer relationship management (eCRM): Opportunities and challenges in a digital world. Irish Marketing Review, 18, 58-68.

Kevork, E. K., \& Vrechopoulos, A. P. (2009). CRM literature: Conceptual and functional insights by keyword analysis. Marketing Intelligence \& Planning, 27, 48-85.

Kim, E., \& Tadisina, S. (2007). A model of customers trust in e-businesses: Micro-level inter-party trust formation. Journal of Computer Information Systems, Fall, 88-104.

Kotler, P., Bowen, J., \& Makens, J. (2003). Marketing for hospitality and tourism ( $3^{\text {rd }}$ ed.). Upper Saddle River, NJ: Prentice Hall.

Li, D., Browne, G. J., \& Wetherbe, J. C. (2007). Online consumers switching behavior: A buyer-seller relationship perspective. Journal of Electronic Commerce in Organizations, 5, 30-42.

Lin, C., \& Huang, Y. (2007). An integrated framework for managing eCRM evaluation process. International Journal of Electronic Business, 5, 340-359.

McCarthy, E. J. (1960). Basic marketing. Homewood: Irwin.

Padmanabhan, B., \& Tuzhilin, A. (2003). On the use of optimization for data mining: Theoretical interactions and eCRM opportunities. Management Science, 49, 1327-1343.

Pitta, D., Franzak, F., \& Fowler, D. (2006). A strategic approach to building online customer loyalty: Integrating customer profitability tiers. Journal of Consumer Marketing, 23, 421-429.

Porter, C. E., \& Donthu, N. (2008). Cultivating trust and harvesting value in virtual communities. Management Science, 54, 113-128.

Salmen, S. M., \& Muir, A. (2003). Electronic customer care: The innovative path to e-loyalty. Journal of Financial Services Marketing, 8, 133-144.

Scullin, S. S., Fjermestad, J., \& Romano, N. C., Jr. (2004). E-relationship marketing: Changes in traditional marketing as an outcome of electronic customer relationship management. The Journal of Enterprise Information Management, 17, 410-415. 
Strauss, A., \& Corbin, J. (1990). Basics of qualitative research: Grounded theory procedures and techniques. Newbury Park, CA: Sage Publications.

Swift, R.S. (2002). Analytical CRM powers profitable relationships: Creating success by letting customers guide you. Data Mining Review, February.

Szmigin, I., Canning, L., \& Reppel, A. E. (2005). Online community: Enhancing the relationship marketing concept through customer bonding. International Journal of Service Industry Management, 16, 180196.

Walczuch, R., \& Lundgren, H. (2004). Psychological antecedents of institution-based consumer trust in etailing. Information \& Management, 42, 159-177.

Wang, Y. D., \& Emurian H. H. (2005). An overview of online trust: Concepts, elements, and implications. Computers in Human Behavior, 21, 105-125.

Yen, H. J. R., \& Gwinner, K. P. (2003). Internet retail customer loyalty: The mediating role of relational benefits. International Journal of Service Industry Management, 14, 483-500.

Yin, R. (2003). Case study research: Design and methods. London: Sage Publications.

\section{Appendix}

Final Thematic Coding Schema by Stakeholder Group

\begin{tabular}{|c|c|c|c|}
\hline $\begin{array}{c}\text { eCRM } \\
\text { Vendor } \\
(\mathrm{n}=1)\end{array}$ & $\begin{array}{c}\text { Company } \\
\text { Management } \\
(n=3)\end{array}$ & $\begin{array}{c}\text { Franchisee } \\
\text { Owners } \\
(n=6)\end{array}$ & $\begin{array}{c}\text { Retail } \\
\text { Customers } \\
(\mathbf{n}=3)\end{array}$ \\
\hline & $\begin{array}{l}\text { Human Accessibility } \\
\text { (2) }\end{array}$ & Human Accessibility (2) & Human Accessibility (3) \\
\hline \multirow[t]{3}{*}{$\begin{array}{l}\text { Importance of Relation- } \\
\text { ship to drive Loyalty and } \\
\text { avoid Loyalty Leakage }\end{array}$} & $\begin{array}{l}\text { Importance of Rela- } \\
\text { tionship to drive Loy- } \\
\text { alty, Interaction and } \\
\text { Connection. }\end{array}$ & $\begin{array}{l}\text { Importance of Relation- } \\
\text { ship to drive Loyalty (4) }\end{array}$ & \\
\hline & & & Appreciation (3) \\
\hline & Problem Resolution & & Problem Resolution (3) \\
\hline \multirow[t]{3}{*}{ Doing it Right, Vision } & Doing it right, Vision & $\begin{array}{l}\text { Doing it Right, Vision } \\
\text { (5) }\end{array}$ & Doing it Right, Vision \\
\hline & $\begin{array}{l}\text { Incentives and Value } \\
\text { (3) }\end{array}$ & Incentives and Value (2) & Incentives and Value(3) \\
\hline & & Paperless (5) & Paperless (3) \\
\hline \multirow[t]{5}{*}{ Feedback and Follow-up } & $\begin{array}{l}\text { Feedback and Follow- } \\
\text { up (2) }\end{array}$ & $\begin{array}{l}\text { Feedback and Follow- } \\
\text { up (6) }\end{array}$ & $\begin{array}{l}\text { Feedback and Follow- } \\
\text { up (3) }\end{array}$ \\
\hline & $\begin{array}{l}\text { Intrusive/Privacy Inde- } \\
\text { pendence and Use } \\
\text { Concerns } \mathrm{d} / \mathrm{b} \text {, zee } \\
\text { adoption }\end{array}$ & $\begin{array}{l}\text { Intrusive/Privacy Inde- } \\
\text { pendence and Use Con- } \\
\text { cerns } d / b(4)\end{array}$ & $\begin{array}{l}\text { Intrusive/Privacy Inde- } \\
\text { pendence(2) }\end{array}$ \\
\hline & & & The Sales Pitch (2) \\
\hline & $\begin{array}{l}\text { Control Issues (Fre- } \\
\text { quency of Contact), (2) }\end{array}$ & $\begin{array}{l}\text { Control Issues (Fre- } \\
\text { quency of Contact), (2) }\end{array}$ & Control Issues (3) \\
\hline & Education (2) & & Education \\
\hline \multirow[t]{2}{*}{ Personalization } & Personalization (3) & Personalization (4) & Personalization (3) \\
\hline & & $\begin{array}{l}\text { Trust in Company or } \\
\text { Vendor }\end{array}$ & Trust in Company (2) \\
\hline $\begin{array}{l}\text { Streamlining Transaction } \\
\text { and Solving Distribution } \\
\text { Problem }\end{array}$ & $\begin{array}{l}\text { Streamlining Transac- } \\
\text { tion, can be emo- } \\
\text { tionless }\end{array}$ & $\begin{array}{l}\text { Streamlining Transac- } \\
\text { tion (4) }\end{array}$ & \\
\hline
\end{tabular}




\begin{tabular}{|c|c|c|c|}
\hline $\begin{array}{l}\text { eCRM } \\
\text { Vendor } \\
(\mathbf{n}=1)\end{array}$ & $\begin{array}{c}\text { Company } \\
\text { Management } \\
(n=3)\end{array}$ & $\begin{array}{c}\text { Franchisee } \\
\text { Owners } \\
(n=6)\end{array}$ & $\begin{array}{c}\text { Retail } \\
\text { Customers } \\
(\mathbf{n}=3)\end{array}$ \\
\hline & $\begin{array}{l}\text { Outbound Efforts for } \\
\text { Customer Acquisition }\end{array}$ & $\begin{array}{l}\text { Outbound Efforts for } \\
\text { Customer Acquisition } \\
\text { (3) }\end{array}$ & \\
\hline Need for full integration & $\begin{array}{l}\text { Need for full integra- } \\
\text { tion }\end{array}$ & $\begin{array}{l}\text { Need for full integration } \\
\text { (4) }\end{array}$ & \\
\hline $\begin{array}{l}\text { Customer Convenience } \\
\text { and Choice }\end{array}$ & $\begin{array}{l}\text { Customer Convenience } \\
\text { and Choice (2) }\end{array}$ & $\begin{array}{l}\text { Customer Convenience } \\
\text { and Choice (2) }\end{array}$ & \\
\hline $\begin{array}{l}\text { Low cost = success } \\
\text { "Move quickly" }\end{array}$ & & Low cost $=$ success $(4)$ & \\
\hline \multicolumn{4}{|l|}{ Lead as "Hostage" } \\
\hline & $\begin{array}{l}\text { Vendor's dream v. } \\
\text { reality }\end{array}$ & & \\
\hline & $\begin{array}{l}\text { Risk v. Reward, oppor- } \\
\text { tunity cost }\end{array}$ & & \\
\hline
\end{tabular}

\section{Biographies}

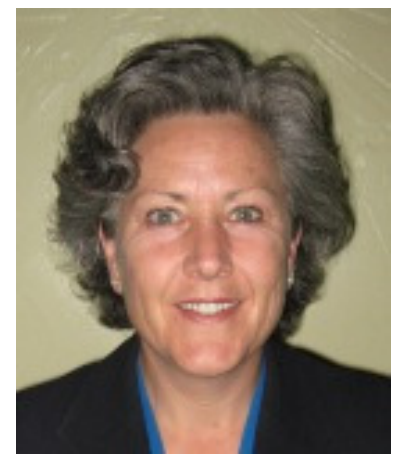

Kelley O'Reilly is a PhD Candidate in Management Information Systems (MIS) at Utah State University. She has more than twenty years of executive level experience in franchise retail and service businesses and has held positions including Senior Vice President of Strategy and Brand Development, Vice President of Sales \& Marketing, and Vice President of Advertising. Her research interests are electronic marketing, customer relationship management (CRM), and improving customer-company interactions. Her work has been published in Qualitative Market Research: An International Journal, and is forthcoming in the Journal of Information Technology Case and Application Research, the International Journal of E-Business Research and the Encyclopedia of E-Business Development and Management in the Digital Economy.

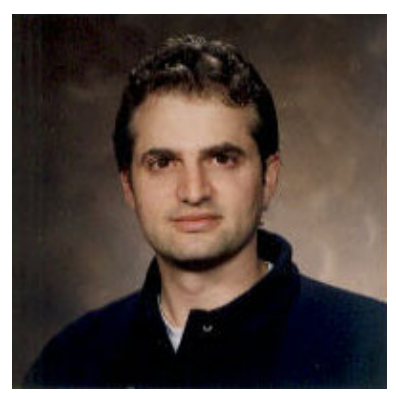

Dr. David Paper is a Professor of MIS in the Jon M. Huntsman School of Business at Utah State University. He has published in leading MIS journals including Communications of the ACM, Information and Management, Information Resources Management Journal, Communications of the AIS, and Long Range Planning. He has worked for Texas Instruments, DLS, Inc., and the Phoenix Small Business Administration. He has conducted research with Wells Fargo, Monsanto, Caterpillar, Honeywell, Fannie Mae, Safeco, Comdisco, Ralston Purina, Moore BCS, and Bank of America. He has performed consulting work with IBM, AT\&T, OCTEL Voice Messaging, Utah Department of Transportation, and Space Dynamics Laboratory. His teaching and research interests include change management, electronic commerce, customer relationship management (CRM), and enterprise integration. 